\title{
Effective alkaline metal-catalyzed oxidative delignification of hybrid poplar
}

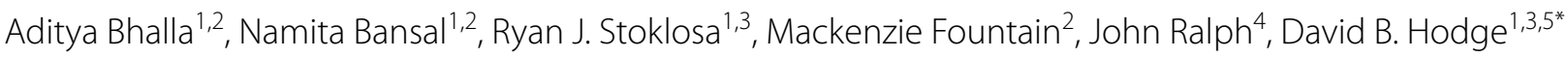 \\ and Eric L. Hegg ${ }^{1,2^{*}}$
}

\begin{abstract}
Background: Strategies to improve copper-catalyzed alkaline hydrogen peroxide (Cu-AHP) pretreatment of hybrid poplar were investigated. These improvements included a combination of increasing hydrolysis yields, while simultaneously decreasing process inputs through (i) more efficient utilization of $\mathrm{H}_{2} \mathrm{O}_{2}$ and (ii) the addition of an alkaline extraction step prior to the metal-catalyzed AHP pretreatment. We hypothesized that utilizing this improved process could substantially lower the chemical inputs needed during pretreatment.
\end{abstract}

Results: Hybrid poplar was pretreated utilizing a modified process in which an alkaline extraction step was incorporated prior to the $\mathrm{Cu}$-AHP treatment step and $\mathrm{H}_{2} \mathrm{O}_{2}$ was added batch-wise over the course of $10 \mathrm{~h}$. Our results revealed that the alkaline pre-extraction step improved both lignin and xylan solubilization, which ultimately led to improved glucose ( $86 \%$ ) and xylose (95\%) yields following enzymatic hydrolysis. An increase in the lignin solubilization was also observed with fed-batch $\mathrm{H}_{2} \mathrm{O}_{2}$ addition relative to batch-only addition, which again resulted in increased glucose and xylose yields (77 and $93 \%$ versus 63 and $74 \%$, respectively). Importantly, combining these strategies led to significantly improved sugar yields ( $96 \%$ glucose and $94 \%$ xylose) following enzymatic hydrolysis. In addition, we found that we could substantially lower the chemical inputs (enzyme, $\mathrm{H}_{2} \mathrm{O}_{2}$, and catalyst), while still maintaining high product yields utilizing the improved Cu-AHP process. This pretreatment also provided a relatively pure lignin stream consisting of $\geq 90 \%$ Klason lignin and only $3 \%$ xylan and $2 \%$ ash following precipitation. Two-dimensional heteronuclear single-quantum coherence (2D HSQC) NMR and size-exclusion chromatography demonstrated that the solubilized lignin was high molecular weight $\left(M_{w} \approx 22,000 \mathrm{Da}\right)$ and only slightly oxidized relative to lignin from untreated poplar.

Conclusions: This study demonstrated that the fed-batch, two-stage Cu-AHP pretreatment process was effective in pretreating hybrid poplar for its conversion into fermentable sugars. Results showed sugar yields near the theoretical maximum were achieved from enzymatically hydrolyzed hybrid poplar by incorporating an alkaline extraction step prior to pretreatment and by efficiently utilizing $\mathrm{H}_{2} \mathrm{O}_{2}$ during the $\mathrm{Cu}$-AHP process. Significantly, this study reports high sugar yields from woody biomass treated with an AHP pretreatment under mild reaction conditions.

Keywords: Alkaline hydrogen peroxide (AHP) pretreatment, Biomass conversion, Catalysis, Cellulosic biofuels, Copper, Hybrid poplar, Lignin, Oxidative delignification, Sugars

\section{Background}

Sustainably produced lignocellulosic biomass is a promising feedstock for the production of petroleum-displacing liquid transportation fuels $[1,2]$. Structural

\footnotetext{
*Correspondence: hodgeda@egr.msu.edu; erichegg@msu.edu ${ }^{1}$ DOE Great Lakes Bioenergy Research Center, Michigan State University, East Lansing, USA

Full list of author information is available at the end of the article
}

polysaccharides (i.e., cellulose and hemicelluloses) comprise the majority of the mass of plants and are amenable to biochemical and/or catalytic conversion, serving as non-food alternatives to starch- and sucrose-derived biofuels [2]. However, plant cell walls exhibit recalcitrance to these approaches to deconstruction and conversion due to a variety of cell wall properties that include higher order structures across multiple length scales [3]. 
Foremost among these features contributing to cell wall recalcitrance is lignin, which limits access of hydrolytic enzymes to these fermentable sugars [4].

Relative to herbaceous biomass, woody biomass has attractive features as a feedstock for the production of renewable fuels and chemicals due to its higher bulk density and year-round availability that facilitates feedstock logistics $[5,6]$. Unfortunately, woody biomass can also be substantially more recalcitrant to deconstruction and conversion than graminaceous feedstocks (i.e., grasses) due, in part, to the high lignin content [7]. For deconstruction routes employing enzymatic hydrolysis, pretreatment is an essential step necessary to remove, modify, and/or redistribute the lignin $[8,9]$. Many of the existing reported pretreatment approaches for hardwoods, however, are capital intensive and require high temperature and/or pressure [3, 10-12].

Delignifying alkaline pretreatments (as well as alkaline pulping technologies) overcome cell wall recalcitrance by chemically modifying and/or cleaving lignin to increase its solubility in alkali $[13,14]$. Furthermore, depending on the conditions used for pretreatment, a substantial fraction of the hemicelluloses may also be solubilized and potentially degraded [15]. Therefore, in addition to improving biomass enzymatic digestibility by removing lignin, alkaline pretreatments can also be considered as biomass fractionation processes that have the capacity to provide a separate lignin stream that can be valorized to additional coproducts $[13,16,17]$.

Alkaline-oxidative pretreatments such as alkaline hydrogen peroxide (AHP) have been shown to be effective pretreatments for herbaceous feedstocks [18-23] as well as for woody biomass [24-26], although these approaches have often employed prohibitively high oxidant loadings on the biomass (e.g., 250 to greater than $2000 \mathrm{mg} \mathrm{H}_{2} \mathrm{O}_{2}$ per $\mathrm{g}$ biomass). We recently discovered that adding small amounts of copper 2,2'-bipyridine complexes $[\mathrm{Cu}(\mathrm{bpy})]$ during AHP pretreatment $(\mathrm{Cu}-$ AHP) resulted in substantially improved sugar yields following enzymatic hydrolysis relative to AHP pretreatment in the absence of the copper catalyst (AHP-only) at modest oxidant loadings (e.g., 25 to $100 \mathrm{mg} \mathrm{H}_{2} \mathrm{O}_{2}$ per $\mathrm{g}$ biomass) [27, 28].

In this manuscript, we describe a combination of strategies to increase the effectiveness of $\mathrm{Cu}$-AHP as well as reduce the chemical inputs to improve the process economics. These enhancements include (i) the addition of an alkaline extraction step prior to $\mathrm{Cu}$-AHP pretreatment and (ii) the more efficient utilization of $\mathrm{H}_{2} \mathrm{O}_{2}$. Together these modifications substantially increased lignin and xylan removal, which resulted in significantly improved sugar yields following enzymatic hydrolysis. In addition, this modified process also yielded relatively pure and unmodified lignin compatible with subsequent valorization.

\section{Results and discussion}

\section{Fed-batch addition of $\mathrm{H}_{2} \mathrm{O}_{2}$}

Hydrogen peroxide represents an important contribution of the cost associated with AHP pretreatment [19, 29], and identifying strategies to reduce the $\mathrm{H}_{2} \mathrm{O}_{2}$ loading without compromising sugar yields would therefore lead to substantial improvements in the operating costs. $\mathrm{H}_{2} \mathrm{O}_{2}$ spontaneously disproportionates to $\mathrm{O}_{2}$ and water in a concentration-dependent reaction under alkaline conditions near its $\mathrm{p} K_{\mathrm{a}}$ of 11.5 [21]. We hypothesized that by lowering the effective $\mathrm{H}_{2} \mathrm{O}_{2}$ concentration during the reaction, these non-productive reactions might be decreased, enabling more of the reactive oxygen species to react with the biomass. To test this hypothesis, we added the $\mathrm{H}_{2} \mathrm{O}_{2}$ in small batches during the course of the pretreatment without changing either the total amount of oxidant utilized or the pretreatment time. Relative to the reference case where all of the $\mathrm{H}_{2} \mathrm{O}_{2}$ was added at the beginning of the pretreatment, this modification resulted in a $\sim 1.2$ fold increase in sugar yields (77\% glucose and $93 \%$ xylose) following enzymatic hydrolysis (Fig. 1; Additional file 1: Table S1). This strategy has also been reported in the literature where $\mathrm{H}_{2} \mathrm{O}_{2}$ was added in a fedbatch manner to avoid its unproductive decomposition during epoxidation [30-32] and hydroxylation [33-35] reactions.

To ascertain how fed-batch addition of $\mathrm{H}_{2} \mathrm{O}_{2}$ alters the cell wall composition of hybrid poplar relative to the reference case, compositional analysis of the biomass was performed both before and after pretreatment. The results revealed that the major impact of fed-batch addition of $\mathrm{H}_{2} \mathrm{O}_{2}$ was an increase in the extent of lignin removal, with approximately $44 \%$ of the original lignin solubilized relative to only $28 \%$ for the reference case (Fig. 2; Additional file 1: Table S2). Delignification is well known to improve enzymatic hydrolysis sugar yields by improving hydrolytic enzymes' access to the cellulose [15, $36,37]$.

\section{Two-stage pretreatment employing alkaline pre-extraction}

Seeking to increase further the efficacy of the pretreatment process, we incorporated an alkaline extraction step prior to the $\mathrm{Cu}$-AHP pretreatment. The rationale was that removing easily extracted hemicellulose and lignin might improve penetration of the $\mathrm{Cu}(\mathrm{bpy})$ complexes into the plant cell wall, thereby leading to more effective targeting of the active radical species to unextracted cell wall lignin. In addition, this step would also remove extractives and easily solubilized lignin, potentially reducing the inhibition of enzymes during 

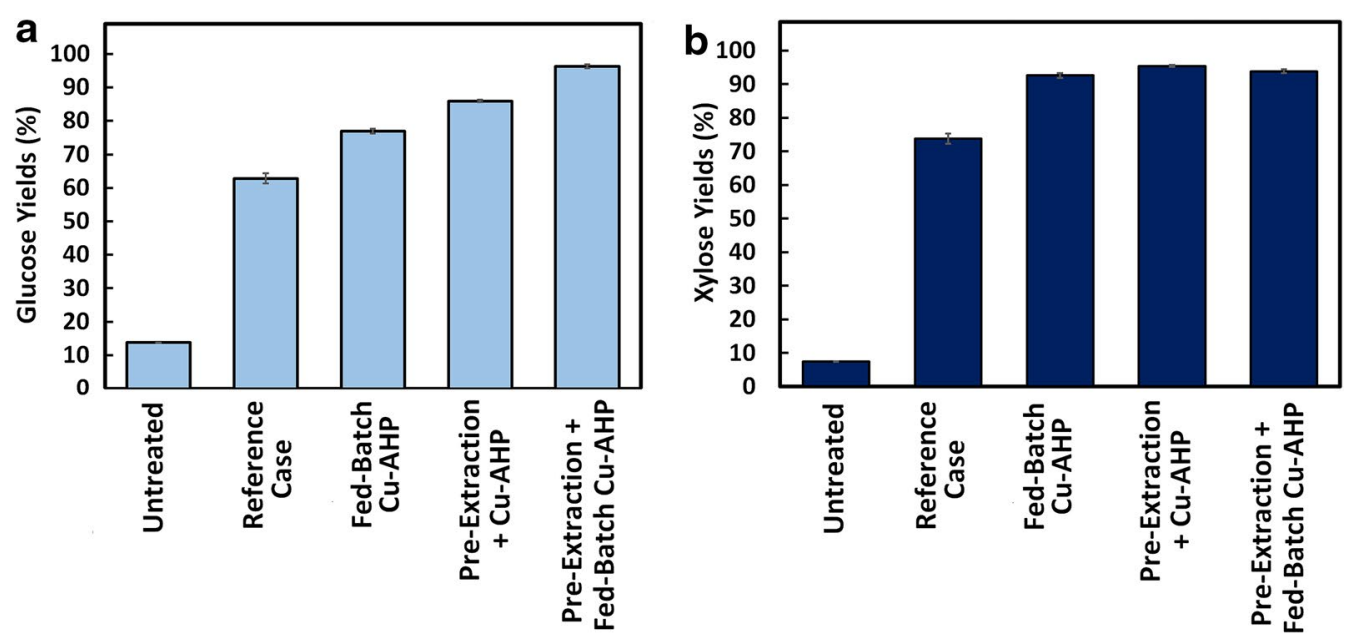

Fig. 1 Glucose (a) and xylose (b) yields obtained following enzymatic hydrolysis of hybrid poplar pretreated under our standard (reference case) or our modified Cu-AHP conditions. Fed-batch Cu-AHP indicates fed-batch addition of $\mathrm{H}_{2} \mathrm{O}_{2}$ and pre-extraction refers to alkaline pre-extraction prior to $\mathrm{Cu}$-AHP pretreatment. The points are the averages of three biological replicates, and error bars indicate \pm standard deviations of the means

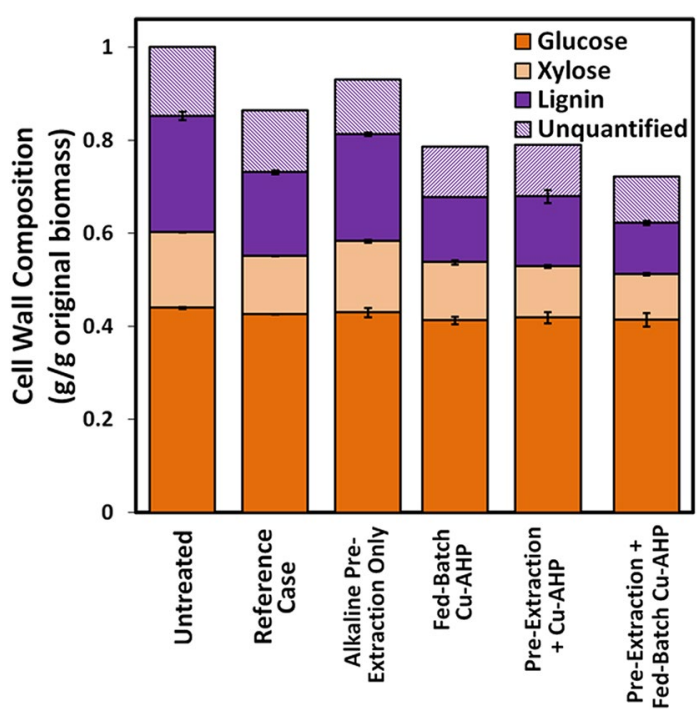

Fig. 2 Mass loss and cell wall composition change associated with pretreatments under standard (reference case) or modified Cu-AHP conditions. Fed-batch Cu-AHP indicates fed-batch addition of $\mathrm{H}_{2} \mathrm{O}_{2}$ and pre-extraction refers to alkaline pre-extraction prior to $\mathrm{Cu}-\mathrm{AHP}$ pretreatment. The values reported are the averages of the three biological replicates, and the error bars indicate \pm standard deviations of the means

hydrolysis. This strategy is comparable to coupling alkaline delignification with an oxidative post-treatment utilized in the established processes for chemical pulping and oxidative bleaching or delignification of wood in the pulp and paper industry [38]. Liu et al. [39] previously employed a similar approach with corn stover, coupling an alkaline pre-extraction with an AHP post-treatment at only $25 \mathrm{mg} \mathrm{H}_{2} \mathrm{O}_{2} / \mathrm{g}$ biomass, and they achieved neartheoretical glucose yields following hydrolysis at modest enzyme loadings. In addition, Koo et al. [40] and Draude et al. [41] demonstrated improved sugar yields utilizing alkaline pretreatment followed by oxygen delignification as a post pretreatment. Finally, Yuan et al. [42] demonstrated effective and synergistic lignin and hemicelluloses removal from poplar using a two-step alkaline and ionic liquid pretreatment. As a further benefit, alkaline preextraction can be performed on wood chips [15], which subsequently reduces the energy required for effective comminution relative to non-pre-extracted biomass.

Based on the final sugar yields (Fig. 1), the alkaline pre-extraction step had a large positive impact on enzymatic hydrolysis yields. Relative to the single-stage reference case, the addition of the alkaline pre-extraction step improved glucose yields from 63 to $86 \%$ and xylose yields from 74 to $95 \%$ (Fig. 1; Additional file 1: Table S1). Compositional analysis following alkaline pre-extraction of hybrid poplar indicated that whereas $\sim 5 \%$ of both the lignin and xylan was solubilized during pre-extraction (Fig. 2; Additional file 1: Table S2), essentially none of the glucose was extracted. It should be noted that under the mild alkaline reaction conditions employed in this study, the xylan should be extensively deacetylated, which aids saccharification, but otherwise be relatively undegraded with a high potential for recovery. Cu-AHP pretreatment of this alkaline pre-extracted poplar resulted in the solubilization of $40 \%$ of the original lignin, which is about 1.4 times higher than in the reference case. Importantly, synergy was observed in the two-stage pretreatment 
approach, with the combined alkaline pre-extraction/CuAHP approach removing nearly $8 \%$ more lignin than the sum of either of the two stages alone. This increased delignification is consistent with the significant increase in sugar yields following enzymatic hydrolysis for the combined two-stage approach.

Hypothesizing that alkaline pre-extraction aids pretreatment, in part, by removing easily extractable lignin, thereby increasing the surface area for easy penetration of metal complexes during pretreatment, we measured the water retention value (WRV) both before and after pre-extraction. Our results indicated that the WRV of hybrid poplar increased from $1.15 \mathrm{~g}$ water/g biomass (untreated) to $1.50 \mathrm{~g}$ water/g biomass following the alkaline pre-extraction step (Additional file 1: Figure S1), consistent with the importance of WRV to the pretreatment process. The swelling of biomass, which increases the internal surface area (as indicated by the WRV), has been observed previously following pretreatment with alkali using $\mathrm{NaOH}, \mathrm{KOH}$, or $\mathrm{Ca}(\mathrm{OH})_{2}$ [43-45].

To ascertain if alkaline pre-extraction also reduced enzyme inhibition by removing extractives and lignin, we evaluated the effect of pre-extraction liquor on the hydrolysis of a model crystalline cellulose substrate (Avicel PH 101). The results demonstrated that enzymatic hydrolysis of Avicel in the presence of alkaline pre-extraction liquor resulted in a $6 \%$ decrease in the glucose yields compared to hydrolysis in buffer only (Additional file 1: Figure S2). It should be noted that this difference was observed under high enzyme loadings $(30 \mathrm{mg} / \mathrm{g}$ glucan) and long incubation times ( $24 \mathrm{~h}$ ), and this effect would likely be magnified at low enzyme loadings and shorter enzymatic hydrolysis times. Together, this result suggests that in addition to biomass swelling, pre-extraction of the hybrid poplar with $\mathrm{NaOH}$ increases sugar yields, at least in part, by removing alkali-extractable compounds that inhibit enzymatic hydrolysis.

\section{Combining alkaline pre-extraction and fed-batch $\mathrm{H}_{2} \mathrm{O}_{2}$ addition}

Having demonstrated that the efficacy of Cu-AHP could be improved dramatically by fed-batch addition of the $\mathrm{H}_{2} \mathrm{O}_{2}$ over the course of the pretreatment as well as by extracting the poplar with alkali prior to $\mathrm{Cu}$-AHP (Fig. 1), we next sought to ascertain if the two strategies could be combined to improve even further the sugar yields. Combining these two strategies resulted in the solubilization of nearly $40 \%$ of the xylan and over $55 \%$ of the lignin during pretreatment (Fig. 2; Additional file 1: Table S2), a substantial improvement over the reference case that did not include either of these modifications. As expected, this increase in lignin and xylan (hemicellulose) removal resulted in a significant improvement in sugar yields
(Fig. 1). In fact, enzymatic hydrolysis resulted in high sugar yields of 96 and $94 \%$ of the theoretical maximum (based on original composition) for glucose and xylose, respectively. Importantly, xylan solubilization did not result in decreases in the xylose yields because the xylan was deacetylated but not degraded and therefore remained available in the pretreatment mixture for enzymatic hydrolysis. It is also important to note that only a small quantity of xylose oligomers was released and subsequently lost during alkaline pre-extraction compared to the xylose oligomers released during the following $\mathrm{Cu}$ AHP step (Fig. 1b).

Several previous studies have examined the effects of a variety of pretreatments on the conversion of hardwoods, and a few have reported high sugar yields $[10,11,36,42$, 46-48]. The pretreatment strategy described herein is performed at atmospheric pressure, and as a result, it can be performed without the added capital costs associated with high pressure and high-temperature reactors. High sugar yields from hybrid poplar have also been reported utilizing metal-catalyzed AHP under standard atmospheric conditions, although these reactions required significantly greater $\mathrm{H}_{2} \mathrm{O}_{2}$ loadings ( $1000 \mathrm{mg} / \mathrm{g}$ biomass) to obtain comparable sugar yields $[26,49]$. To the best of our knowledge, this is the first study that reports high sugar yields (i.e., $>95 \%$ ) from a woody biomass treated with an AHP pretreatment with low $\mathrm{H}_{2} \mathrm{O}_{2}$ loadings under mild reaction conditions (i.e., low temperature and pressure).

\section{Impact of enzyme, $\mathrm{H}_{2} \mathrm{O}_{2}$, and catalyst loadings on fed-batch, two-stage Cu-AHP pretreatment}

Next, a series of experiments were performed to explore the relationship between pretreatment conditions and the biomass response. Specifically, the impacts of $\mathrm{H}_{2} \mathrm{O}_{2}$ and catalyst loading during $\mathrm{Cu}$-AHP pretreatment as well as enzyme loading during enzymatic hydrolysis were investigated with the goals of (1) ascertaining how these variables impact hydrolysis yields and (2) identifying strategies for how these inputs into the process may be minimized, while maintaining high hydrolysis yields. In the first set of experiments, the $\mathrm{H}_{2} \mathrm{O}_{2}$ loading was varied for alkaline pre-extracted biomass while holding the other variables constant, and the impact on lignin removal and hydrolysis yields was determined (Fig. 3). For the reaction conditions used, the results demonstrated that the $\mathrm{H}_{2} \mathrm{O}_{2}$ loading can be reduced by 25 to $75 \mathrm{mg} / \mathrm{g}$ poplar while still maintaining sugar yields over $90 \%$. In fact, even at $\mathrm{H}_{2} \mathrm{O}_{2}$ loadings as low as $50 \mathrm{mg} \mathrm{H}_{2} \mathrm{O}_{2}$ /g biomass, the sugar yields following enzymatic hydrolysis were higher (78 \%) than those obtained in the reference case (63\%) which utilized $100 \mathrm{mg} \mathrm{H}_{2} \mathrm{O}_{2} / \mathrm{g}$ biomass. As expected, compositional analysis of the biomass treated with different $\mathrm{H}_{2} \mathrm{O}_{2}$ loadings revealed a clear relationship between 
the extent of lignin removal and the sugar yields following enzymatic hydrolysis (Fig. 3). Sugar yields increased rapidly with lignin removal until approximately $40 \%$ of the lignin had been removed (to $\sim 14 \%$ final lignin content in the pretreated biomass) at which point additional lignin removal had only a modest effect on sugar yields. A similar threshold value for hydrolysis yields between a Klason lignin content of $10-15 \%$ has been observed by Grabber et al. [50] and Li et al. [44] for grasses subjected to delignification.

Enzymes currently represent an important operating cost in essentially all cellulosic biofuels processes employing an enzymatic deconstruction step [51, 52]. Consequently, there has been considerable focus on improving pretreatment strategies to enable lower enzyme loadings to be used during hydrolysis without sacrificing sugar yields [53]. The first set of experiments described above was performed utilizing high enzyme loadings of $60 \mathrm{mg}$ protein (enzyme) per g glucan. Hypothesizing that the alkaline pre-extraction and the more efficient utilization of $\mathrm{H}_{2} \mathrm{O}_{2}$ might allow us to reduce enzyme loading, we initiated a second set of experiments to correlate glucose yields following enzymatic hydrolysis of pretreated hybrid poplar using different enzyme loadings (Fig. 4). Not surprisingly, there was a strong correlation between enzyme loading and sugar yield. As anticipated, however, alkaline pre-extraction coupled with fed-batch addition of $\mathrm{H}_{2} \mathrm{O}_{2}$ during $\mathrm{Cu}$-AHP treatment resulted in improved sugar yields even at much lower enzyme concentrations. For instance, at $100 \mathrm{mg} \mathrm{H}_{2} \mathrm{O}_{2}$ per gram pop$\operatorname{lar}\left(10 \% \mathrm{H}_{2} \mathrm{O}_{2}\right)$, we were able to reduce enzyme loadings to $15 \mathrm{mg} / \mathrm{g}$ glucan (a fourfold decrease) and still obtain

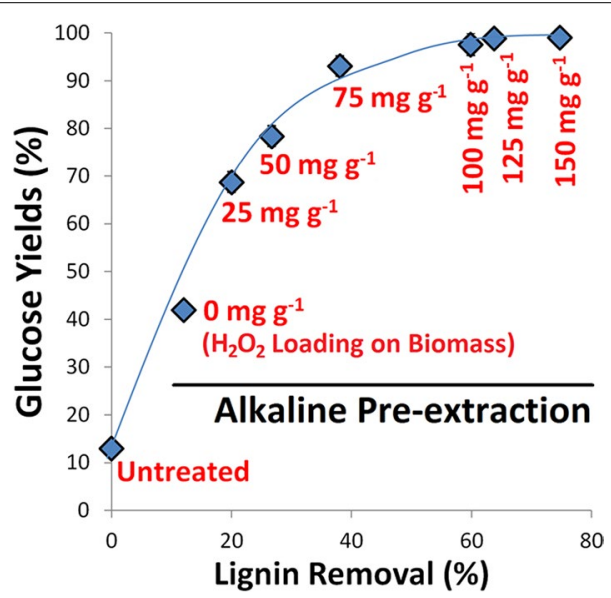

Fig. 3 Correlating glucose yields following enzymatic hydrolysis of alkaline pre-extracted + fed-batch Cu-AHP pretreated hybrid poplar with lignin removal at different $\mathrm{H}_{2} \mathrm{O}_{2}$ loadings. The points are the averages of three separate experiments, and the error bars indicate \pm standard deviations of the means

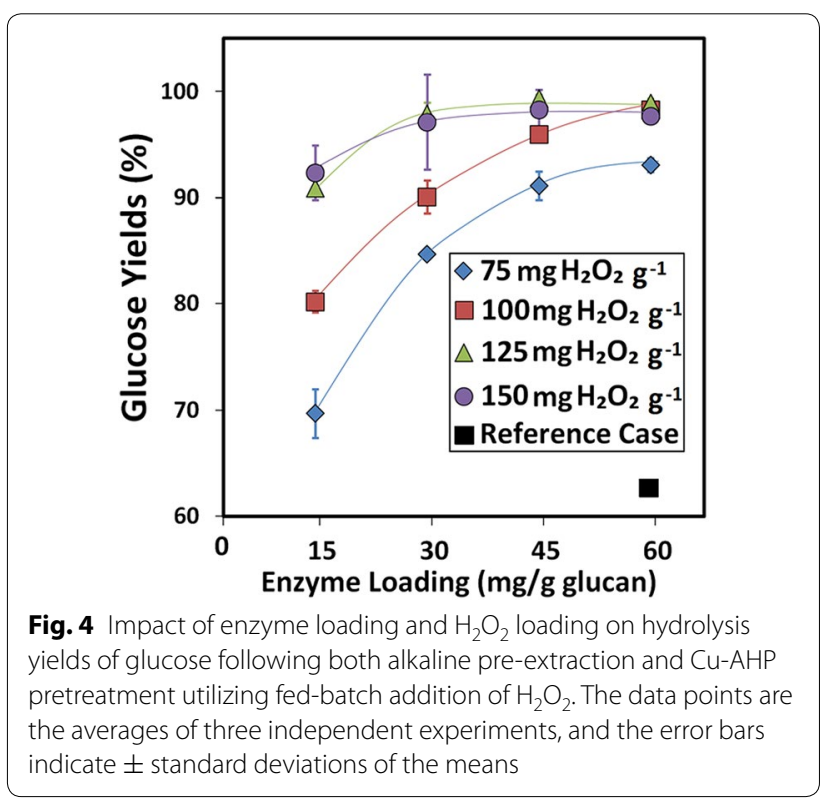

significantly higher glucose yields following enzymatic hydrolysis (approximately 80 versus $60 \%$ for the $\mathrm{Cu}$-AHP reference case conditions). In addition, when $\mathrm{H}_{2} \mathrm{O}_{2}$ loadings were increased to $125 \mathrm{mg} \mathrm{H}_{2} \mathrm{O}_{2} / \mathrm{g}$ biomass, glucose yields increased still further to greater than $90 \%$ while utilizing only $15 \mathrm{mg}$ protein/g glucan. This improved saccharification of pretreated poplar with such low enzyme loadings can be attributed to the relatively high lignin removal during the pretreatment process. Reduced enzyme loadings are vital for making the overall process more cost effective, and several studies have therefore sought to utilize reduced enzyme loadings for the enzymatic hydrolysis step of pretreated woody biomass. Koo et al. [40] and Kumar et al. [54] also demonstrated low enzyme loading during the hydrolysis of mixed hardwood chips and softwood pulp, respectively, following pressurized oxygen pretreatments. In addition, Kim et al. [55] and Yamamoto et al. [56] obtained high sugar yields from woody biomass utilizing low enzyme loadings with liquid hot water and sulfur dioxide-ethanol-water fractionation pretreatments, respectively.

In the third set of experiments, the impacts of the Cu:bpy ratio as well as the enzyme and $\mathrm{H}_{2} \mathrm{O}_{2}$ loadings on hydrolysis yields were determined for the fed-batch $\mathrm{Cu}$ AHP process following alkaline pre-extraction. Figure 5 depicts sugar yields obtained at a catalyst concentration of $1 \mathrm{mM}$ copper with varying ligand:metal ratios, $\mathrm{H}_{2} \mathrm{O}_{2}$ loadings, and enzyme loadings. These results reveal the potential for reduced loadings of costly ligand even at low enzyme loadings of 15 and $30 \mathrm{mg} / \mathrm{g}$ glucan. Glucose hydrolysis yields as high as $75 \%$ were obtained at a ligand concentration of $0.5 \mathrm{mM}, 30 \mathrm{mg} / \mathrm{g}$ glucan enzyme, and 

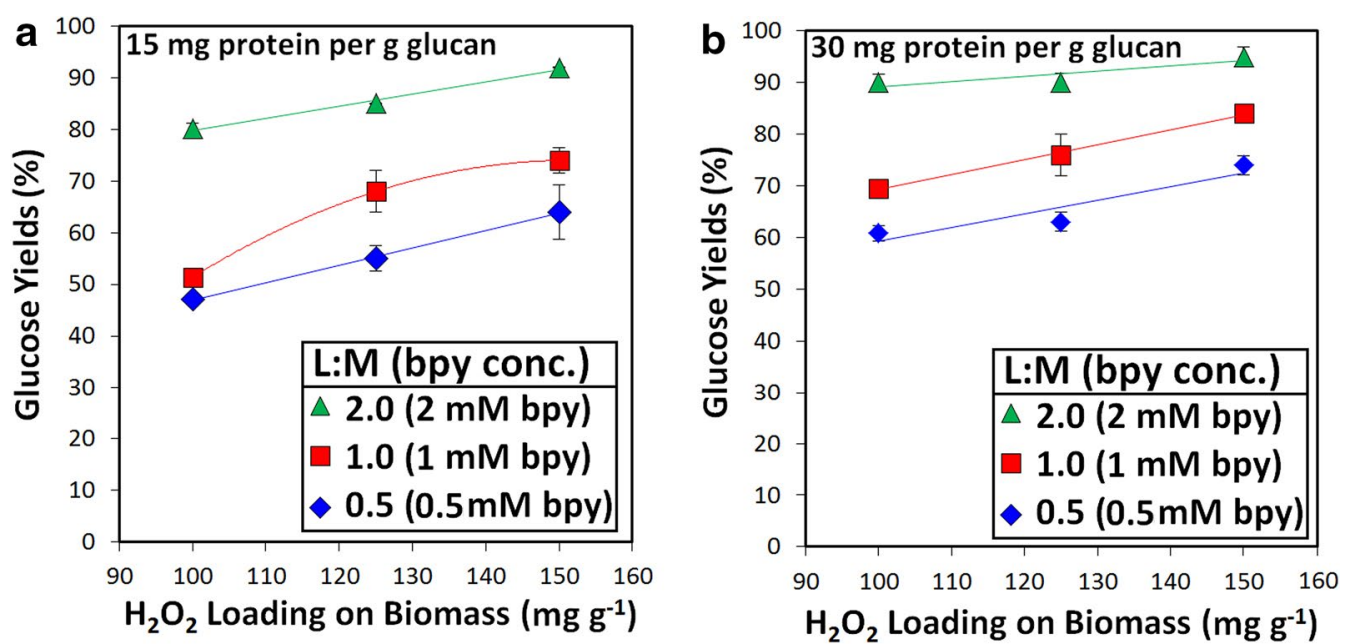

Fig. 5 Impact of $\mathrm{H}_{2} \mathrm{O}_{2}$ loading and bipyridine concentration on glucose yields following alkaline pre-extraction and Cu-AHP pretreatment utilizing fed-batch addition of $\mathrm{H}_{2} \mathrm{O}_{2}$ for enzyme loadings of $\mathbf{a} 15 \mathrm{mg}$ protein per g glucan and $\mathbf{b} 30 \mathrm{mg}$ protein per $\mathrm{g}$ glucan. Pretreatment reactions were

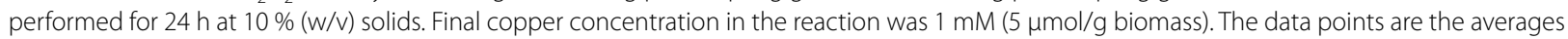
of three independent experiments, and the error bars represent \pm standard deviations of the means

$150 \mathrm{mg} \mathrm{H}_{2} \mathrm{O}_{2}$. An increase in the glucose yields to $85 \%$ was obtained by increasing the bipyridine concentration to $1.0 \mathrm{mM}$ with $30 \mathrm{mg} / \mathrm{g}$ glucan enzyme and $150 \mathrm{mg}$ $\mathrm{H}_{2} \mathrm{O}_{2}$. These results demonstrate the potential of the two-stage pretreatment approach coupled with fed-batch $\mathrm{H}_{2} \mathrm{O}_{2}$ addition to decrease bipyridine loadings.

Although promising, there is a substantial opportunity for process optimization to decrease further these input costs. Potential approaches include (a) decreasing the loading of the process input chemicals and/or enzymes, (b) improved recovery/regeneration of the process input chemicals, and (c) replacement of the process input chemicals with lower cost substitutes. An additional strategy is to optimize the alkaline pre-extraction for the delignification of wood chips, as delignification is known to lower substantially the energy requirements for particle-size reduction [57]. Furthermore, more severe alkaline pre-extraction conditions could be employed which would be expected to both decrease the second-stage treatment requirements and the required enzyme loadings to achieve target hydrolysis yields.

\section{Characterization of $\mathrm{Cu}$-AHP solubilized lignin}

As shown in Fig. 3, the improved pretreatment strategy is capable of solubilizing a significant fraction of the total lignin present in the hybrid poplar. Recognizing that this delignification process not only improves the enzymatic digestibility of the biomass but also provides a lignin stream for potential valorization to chemicals and/or fuels, we sought to characterize the solubilized lignin. The solubilized lignin obtained from the two-stage, fed-batch
$\mathrm{Cu}$-AHP pretreatment was precipitated at $\mathrm{pH} 2$, washed with water, and lyophilized to dryness. Compositional analysis of the recovered product ( $85 \%$ of the total solubilized lignin) indicated that it was relatively pure, containing $\geq 90 \%$ Klason lignin and only $3 \%$ xylan and $2 \%$ ash. Size-exclusion chromatography and two-dimensional heteronuclear single-quantum coherence (2D HSQC) NMR were applied for qualitative analyses of the lignin. The weight average $\left(M_{w}\right)$ and number average $\left(M_{n}\right)$ molecular weights of the lignin were found to be approximately 22,000 and $8000 \mathrm{Da}$, respectively (Fig. 6). This corresponds to an average of approximately 43 monomeric units per lignin polymer assuming a molar mass of $187 \mathrm{~g} /$ mol per lignin monomer. Thus, the lignin obtained after the improved AHP process was of high molecular weight which may assist in its further utilization for value-added products.

We also performed 2D HSQC NMR to ascertain the changes to the chemical structure of the solubilized lignin following the $\mathrm{Cu}$-AHP pretreatment procedure (Additional file 1: Figure S3). Analysis of the spectra obtained for the solubilized lignin indicated the presence of small amounts of oxidized syringyl and guaiacyl units. Interestingly, there was no significant difference in the extent of lignin oxidation by the improved $\mathrm{Cu}$-AHP process (i.e., alkaline extraction of the poplar followed by fed-batch $\mathrm{Cu}$-AHP) compared to the reference case $\mathrm{Cu}$-AHP [58]. Therefore, not only does the improved $\mathrm{Cu}$-AHP process provide higher sugar yields and increased lignin solubilization, but it also preserves the lignin for subsequent valorization. 


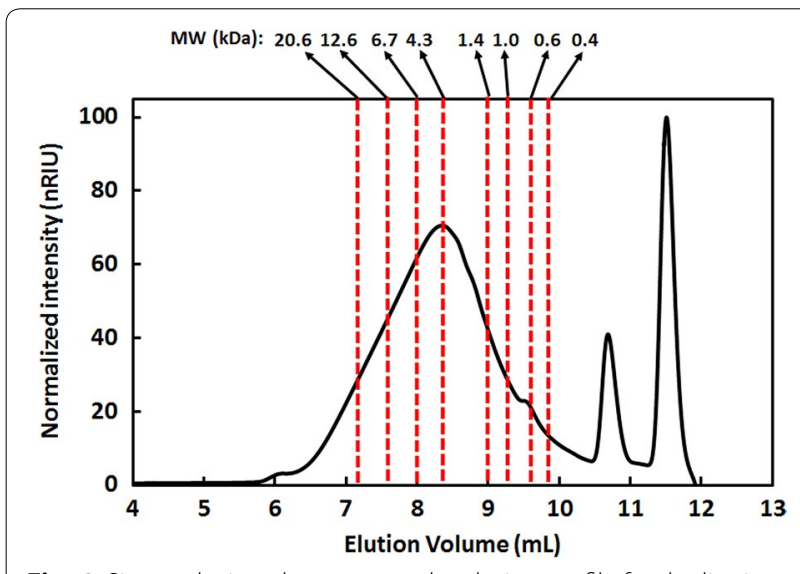

Fig. 6 Size-exclusion chromatography elution profile for the lignin solubilized during $\mathrm{Cu}$-AHP pretreatment with alkaline pre-extraction and fed-batch addition of $\mathrm{H}_{2} \mathrm{O}_{2}$

\section{Conclusions}

Two different strategies were employed to improve $\mathrm{Cu}$ AHP pretreatment of hybrid poplar. First, an alkaline extraction step, which increased biomass porosity and removed extractives that inhibit enzymatic hydrolysis, was introduced prior to $\mathrm{Cu}$-AHP. This modification increased glucose yields from 63 to $86 \%$. In a second strategy, the $\mathrm{H}_{2} \mathrm{O}_{2}$ was utilized more efficiently by employing a fed-batch system, which resulted in an increase in glucose yields from $63 \%$ in the unmodified $\mathrm{Cu}-\mathrm{AHP}$ process to $77 \%$. Significantly, combining these two strategies (i.e., alkaline extraction followed by fedbatch addition of $\mathrm{H}_{2} \mathrm{O}_{2}$ during $\mathrm{Cu}$-AHP) led to glucose and xylose yields that were 96 and $94 \%$, respectively, of theoretical maximum. In addition, clean and relatively unmodified lignin ( $50 \%$ of the original lignin) that is suitable for valorization was also generated. Importantly, experiments performed with different $\mathrm{H}_{2} \mathrm{O}_{2}$, catalyst, and enzyme loadings demonstrated the potential for further reduction of chemical inputs using this improved $\mathrm{Cu}-$ AHP pretreatment process.

\section{Methods}

\section{Biomass and compositional analysis}

Hybrid poplar (Populus nigra var. charkoviensis x caudina cv. NE-19) grown at the University of Wisconsin Arlington Agricultural Research Station was milled to pass through a 20-mesh screen (Thomas Scientific3383L10-Mini-Mill, Thomas-Wiley). The initial compositions of the structural carbohydrates and the acid-insoluble lignin (Klason lignin) were determined using the National Renewable Energy Laboratory (NREL) two-stage acidolysis method [59]. Due to the inability of the Aminex HPX-87H column to resolve mannose and galactose from xylose, the xylose yields and contents reported using this method include mannose and galactose.

\section{Catalytic copper-catalyzed AHP pretreatment (reference case)}

Biomass (0.51 g; 0.50 g dry basis; approximately $3 \%$ moisture content) was pretreated in a total of $5.0 \mathrm{~mL}$ aqueous solution (10\% solids loading). The reference case $\mathrm{Cu}$-AHP pretreatment reaction was carried out by adding $4.33 \mathrm{~mL}$ of distilled water followed by $270 \mu \mathrm{L}$ of $5 \mathrm{M} \mathrm{NaOH}$ (100 mg/g biomass), $125 \mu \mathrm{L}$ of a $40 \mathrm{mM}$ $\mathrm{CuSO}_{4}$ solution, $125 \mu \mathrm{L}$ of a solution containing both

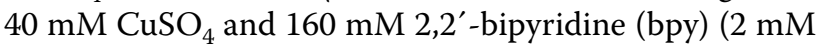
$\mathrm{Cu}^{2+}$ and $4 \mathrm{mM}$ bpy final concentration), and finally $150 \mu \mathrm{L}$ of $30 \% \mathrm{H}_{2} \mathrm{O}_{2}$ (w/w) (100 mg $\mathrm{H}_{2} \mathrm{O}_{2}$ per g biomass; $10 \%$ loading) to the biomass. The reactants were briefly vortexed, and the slurry was incubated with orbital shaking at $180 \mathrm{rpm}$ and $30^{\circ} \mathrm{C}$ for $24 \mathrm{~h}$. The initial $\mathrm{pH}$ for the $\mathrm{Cu}$-AHP pretreatment reaction was approximately 11.5 .

\section{Cu-AHP with fed-batch addition of hydrogen peroxide}

$\mathrm{Cu}$-AHP pretreatment with fed-batch addition of $\mathrm{H}_{2} \mathrm{O}_{2}$ was performed as described above for the reference case except that the $150 \mu \mathrm{L}$ of $30 \% \mathrm{H}_{2} \mathrm{O}_{2}$ (w/w) $(100 \mathrm{mg} / \mathrm{g}$ biomass final loading) was added to the reaction mixture in small batches over a 10-h period. Specifically, each hour $15 \mu \mathrm{L}$ of $30 \% \mathrm{H}_{2} \mathrm{O}_{2}$ was added to the reaction mixture followed by a brief vortex to ensure an even distribution. Following the final addition of $\mathrm{H}_{2} \mathrm{O}_{2}$, the mixture was incubated as described for an additional $14 \mathrm{~h}$ ( $24 \mathrm{~h}$ total reaction time).

\section{Alkaline pre-extraction with Cu-AHP pretreatment}

Alkaline pre-extracted hybrid poplar was prepared by incubating $0.51 \mathrm{~g}(\sim 0.50 \mathrm{~g}$ dry basis) of biomass in $5 \mathrm{~mL}$ (10\% solids loading) of $270 \mathrm{mM} \mathrm{NaOH}(a q)(100 \mathrm{mg} / \mathrm{g}$ biomass final $\mathrm{NaOH}$ loading) at $30^{\circ} \mathrm{C}$ for $1 \mathrm{~h}$. After $1 \mathrm{~h}$ of incubation, the remaining insoluble biomass was washed with one volume of deionized water and subjected to $23 \mathrm{~h}$ of $\mathrm{Cu}$-AHP pretreatment $(24 \mathrm{~h}$ total reaction time including the 1-h pretreatment) as described above.

\section{Combined alkaline pre-extraction and Cu-AHP using fed-batch $\mathrm{H}_{2} \mathrm{O}_{2}$ addition}

Alkaline pre-extraction and fed-batch $\mathrm{H}_{2} \mathrm{O}_{2}$ addition strategies were combined in the modified $\mathrm{Cu}$-AHP pretreatment. Hybrid poplar biomass $(0.51 \mathrm{~g}$ or $\sim 0.50 \mathrm{~g}$ dry weight) was subjected to alkaline pre-extraction, washed with one volume of deionized water, and pretreated with $\mathrm{Cu}$-AHP using fed-batch addition of $\mathrm{H}_{2} \mathrm{O}_{2}$ as described above except that the concentration of the $\mathrm{Cu}$ (bpy) complexes was reduced by $50 \%$ (i.e., to $1.0 \mathrm{mM} \mathrm{Cu}^{2+}$ and 
$2.0 \mathrm{mM}$ bpy total final concentrations). Note that whenever a different concentration of any of the reactants was used to probe the effect on the pretreatment process, an appropriate amount of distilled water was added to the reaction mixture to maintain a final solid biomass loading of $10 \%$.

\section{Enzymatic hydrolysis}

Following pretreatment, the reaction mixture $(5 \mathrm{~mL}$ aqueous plus $\sim 0.5 \mathrm{~g}$ biomass) was combined with $0.5 \mathrm{~mL}$ of $1 \mathrm{M}$ citric acid buffer ( $\mathrm{pH} 5.0$ ) and $4.3 \mathrm{~mL}$ of deionized water, and the slurry was slowly titrated with $72 \%(\mathrm{w} / \mathrm{w}) \mathrm{H}_{2} \mathrm{SO}_{4}$ to adjust the $\mathrm{pH}$ to 5.0 prior to enzymatic hydrolysis. An enzyme cocktail consisting of Cellic CTec3 and HTec3 (kindly provided by Novozymes A/S, Bagsværd, DK) at a loading of $30 \mathrm{mg}$ protein/g glucan each unless otherwise noted was added to the hydrolysis reaction. The total aqueous volume of the reaction was then adjusted to $10 \mathrm{~mL}$ (5\% solids loading) by the addition of $\sim 100 \mathrm{uL}$ deionized water, and the samples were incubated at $50{ }^{\circ} \mathrm{C}$ for $72 \mathrm{~h}$ with orbital shaking at $210 \mathrm{rpm}$. Following enzymatic hydrolysis, the reaction contents were centrifuged, the $\mathrm{pH}$ was measured again to ensure there was no drift, and the amount of glucose and xylose in the supernatant was quantified by high-performance liquid chromatography (HPLC) (Agilent 1260 Series equipped with an infinity refractive index detector) using an Aminex $\mathrm{HPX}-87 \mathrm{H}$ column operating at $65{ }^{\circ} \mathrm{C}$, a mobile phase of $5.0 \mathrm{mM}$ $\mathrm{H}_{2} \mathrm{SO}_{4}$, and a flow rate of $0.6 \mathrm{~mL} / \mathrm{min}$. Standard curves using pure glucose and xylose were prepared prior to each analysis to convert peak area to concentration of monomeric sugar. The sugar yields (glucose and xylose) were calculated by dividing the amount of released sugar by the total sugar content of the biomass prior to pretreatment. The error bars in the figures represent the standard deviation from three or more biological replicates.

\section{Water retention value (WRV)}

WRV was determined according to a modified version of TAPPI UM 256 [45]. After alkaline pre-extraction, the biomass ( $2 \mathrm{~g}$ ) was washed with deionized water and vacuum-filtered to a moisture content of approximately $80 \%$. The washed wet biomass was inserted into a spin column (Handee Spin Column Cs4, Thermo Scientific) modified to have a 200 mesh stainless steel screen as the membrane directly under the biomass. The spin columns were then centrifuged at $900 \mathrm{~g}$ for $15 \mathrm{~min}$. After centrifugation, the biomass was weighed and placed in an aluminum tray at $105^{\circ} \mathrm{C}$ for $3 \mathrm{~h}$. The WRV value was calculated as the ratio of the mass of water retained by the wet biomass after centrifugation to the oven dry mass of the same biomass sample.

\section{Enzyme inhibition studies}

Avicel $(0.2 \mathrm{~g})$ was mixed with $2.5 \mathrm{~mL}$ of the alkaline extraction liquor used to perform a prior pre-extraction reaction, followed by the addition of $0.25 \mathrm{~mL}$ of $1 \mathrm{M}$ citric acid buffer ( $\mathrm{pH}$ 5.0) and $2 \mathrm{~mL}$ of deionized water. The slurry was slowly titrated with $72 \%$ (w/w) $\mathrm{H}_{2} \mathrm{SO}_{4}$ to adjust the $\mathrm{pH}$ to 5.0 prior to enzymatic hydrolysis. Following the addition of Cellic CTec3 at a loading of $30 \mathrm{mg}$ protein/g glucan, the total aqueous volume of the enzymatic hydrolysis reaction was adjusted to $5 \mathrm{~mL}$ by the addition of deionized water ( $4 \%$ solids loading), and the samples were incubated at $50{ }^{\circ} \mathrm{C}$ for $72 \mathrm{~h}$ with orbital shaking at $210 \mathrm{rpm}$. The $\mathrm{pH}$ was measured again at the end of hydrolysis to ensure that it was maintained at $~ 5.0$.

\section{Lignin preparation}

Following $\mathrm{Cu}$-AHP pretreatment, the liquid phase was separated from the solid phase via filtration and the filtrate was acidified to $\mathrm{pH} 2.0$ with $72 \%(\mathrm{w} / \mathrm{w})$ sulfuric acid. The precipitate was recovered by filtration, washed with aqueous sulfuric acid ( $\mathrm{pH} 2.0)$, and finally washed by resuspending in deionized water. The suspension was centrifuged to remove the liquid phase. The precipitate was collected and lyophilized prior to analysis via sizeexclusion chromatography and 2D HSQC NMR. Compositional analysis of lyophilized lignin was performed using the NREL two-stage acidolytic method [59].

\section{Lignin characterization}

To analyze the lignin via size-exclusion chromatography, the lyophilized lignin samples were dissolved in a 80:20 (v/v) solution of $0.1 \mathrm{M} \mathrm{NaNO}_{3}: 0.005 \mathrm{M} \mathrm{NaOH} / \mathrm{CH}_{3} \mathrm{CN}$, syringe-filtered $(0.22 \mu \mathrm{m})$, and loaded onto an Agilent 1260 series HPLC equipped with a Waters Ultrahydrogel $^{\mathrm{TM}} 250$ (Milford, MA, USA) column. The mobile phase was also an 80:20 (v/v) mixture of 0.1 $\mathrm{M} \mathrm{NaNO}_{3}: 0.005 \mathrm{M}$ $\mathrm{NaOH} / \mathrm{CH}_{3} \mathrm{CN}$ at a flow rate of $0.6 \mathrm{~mL} \mathrm{~min}{ }^{-1}$ at $45{ }^{\circ} \mathrm{C}$. The lignin was detected using an Agilent 1260 infinity refractive index detector (RID) detector. Polyethylene glycol (PEG) standards (0.4, 0.6, 1.0, 1.4, 4.3, 6.7, 12.6, and $20.6 \mathrm{kDa}$; Waters ${ }^{\mathrm{TM}}$ ) were run on the system to generate a standard curve. Based on the reference elution volumes, the number average $\left(M_{n}\right)$ and weight average $\left(\mathrm{M}_{\mathrm{w}}\right)$ molecular weights were calculated. The number of monomeric units was calculated by utilizing an approximate molecular weight of a lignin monomer as $\sim 187 \mathrm{~g} /$ mol. 2D HSQC NMR was performed on the solubilized lignin according to the procedure outlined in $\mathrm{Li}$ et al. [58]. 


\section{Additional file}

Additional file 1. Table S1. Sugar yields obtained from different pretreatment strategies. Table S2. Percent mass loss obtained after different pretreatments. Figure S1. Water retention value (WRV) for untreated biomass and alkaline pre-extracted biomass. Figure S2. Enzymatic hydrolysis inhibition studies using Avicel as a substrate. Figure S3. Partial 2D HSQC NMR spectra of (A) lignin from untreated, debarked whole poplar, (B) solubilized lignin from reference case CU-AHP pretreated poplar, and (C) solubilized lignin from modified CU-AHP pretreated poplar.

\section{Abbreviations}

AHP: alkaline hydrogen peroxide; AIR: alcohol insoluble residue; bpy: 2,2'-bipyridine; Cu-AHP: copper-catalyzed alkaline hydrogen peroxide; Da: dalton; HPLC: high-performance liquid chromatography; HSQC: heteronuclear singlequantum coherence; $M_{n}$ : number average molecular weight; $M_{w}$ : weight average molecular weight; NMR: nuclear magnetic resonance; NREL: National Renewable Energy Laboratory; PEG: polyethylene glycol; RID: refractive index detector; TAPPI: Technical Association of the Pulp and Paper Industry; WRV: water retention value.

\section{Authors' contributions}

$\mathrm{ELH}, \mathrm{DBH}$, and $\mathrm{AB}$ conceived the work; $\mathrm{AB}, \mathrm{RS}, \mathrm{ELH}$, and DBH wrote the manuscript; $A B$ and NB performed the pretreatment, composition analysis, and enzymatic hydrolysis; MF performed enzyme inhibition experiments; $A B$ and RS analyzed the lignin via size-exclusion chromatography; and JR analyzed the HSQC NMR spectra. All authors provided input and corrections to the manuscript. All authors read and approved the final manuscript.

\section{Author details}

${ }^{1}$ DOE Great Lakes Bioenergy Research Center, Michigan State University, East Lansing, USA. ${ }^{2}$ Department of Biochemistry and Molecular Biology, Michigan State University, East Lansing, USA. ${ }^{3}$ Department of Chemical Engineering and Materials Science, Michigan State University, East Lansing, USA. ${ }^{4}$ DOE Great Lakes Bioenergy Research Center, University of Wisconsin-Madison, Madison, USA. ${ }^{5}$ Division of Sustainable Process Engineering, Luleå University of Technology, Luleå, Sweden.

\section{Acknowledgements}

We thank Ali Azarpira for performing the NMR measurements. This work was funded by the DOE Great Lakes Bioenergy Research Center (DOE BER Office of Science DE-FC02-07ER64494).

\section{Competing interests}

The authors declare that they have no competing interests.

Received: 14 December 2015 Accepted: 20 January 2016 Published online: 09 February 2016

\section{References}

1. Limayem A, Ricke SC. Lignocellulosic biomass for bioethanol production: current perspectives, potential issues and future prospects. Prog Energ Combust. 2012;38:449-67.

2. Hamelinck CN, van Hooijdonk G, Faaij APC. Ethanol from lignocellulosic biomass: techno-economic performance in short-, middle- and longterm. Biomass Bioenerg. 2005;28:384-410.

3. Gao J, Anderson D, Levie B. Saccharification of recalcitrant biomass and integration options for lignocellulosic sugars from Catchlight Energy's sugar process (CLE Sugar). Biotechnol Biofuels. 2013;6:10.

4. Zhao XB, Zhang LH, Liu DH. Biomass recalcitrance. Part I: the chemical compositions and physical structures affecting the enzymatic hydrolysis of lignocellulose. Biofuel Bioprod Bior. 2012;6:465-82.

5. Porth I, El-Kassaby YA. Using Populus as a lignocellulosic feedstock for bioethanol. Biotechnol J. 2015;10:510-24.
6. Sannigrahi P, Ragauskas AJ, Tuskan GA. Poplar as a feedstock for biofuels: a review of compositional characteristics. Biofuel Bioprod Bior. 2010;4:209-26.

7. Fu C, Mielenz JR, Xiao X, Ge Y, Hamilton CY, Rodriguez M Jr, Chen F, Foston $M$, Ragauskas A, Bouton J, et al. Genetic manipulation of lignin reduces recalcitrance and improves ethanol production from switchgrass. Proc Natl Acad Sci USA. 2011;108:3803-8.

8. Mosier N, Wyman C, Dale B, Elander R, Lee YY, Holtzapple M, Ladisch M. Features of promising technologies for pretreatment of lignocellulosic biomass. Bioresour Technol. 2005;96:673-86.

9. Ong RG, Chundawat SPS, Hodge DB, Keskar S, Dale BE. Linking plant biology and pre- treatment: understanding the structure and organization of the plant cell wall and interactions with cellulosic biofuel production. In: McCann MC, Buckeridge MS, Carpita NC, editors. Plants and BioEnergy. New York: Springer; 2014. p. 231-53.

10. Yan $L$, Zhang $L$, Yang B. Enhancement of total sugar and lignin yields through dissolution of poplar wood by hot water and dilute acid flow through pretreatment. Biotechnol Biofuels. 2014;7:76.

11. Jin Y, Yang L, Jameel H, Chang HM, Phillips R. Sodium sulfite-formaldehyde pretreatment of mixed hardwoods and its effect on enzymatic hydrolysis. Bioresour Technol. 2013;135:109-15.

12. Arantes V, Gourlay K, Saddler JN. The enzymatic hydrolysis of pretreated pulp fibers predominantly involves "peeling/erosion" modes of action. Biotechnol Biofuels. 2014;7:87.

13. Ragauskas AJ, Beckham GT, Biddy MJ, Chandra R, Chen F, Davis MF, Davison $\mathrm{BH}$, Dixon RA, Gilna P, Keller M, et al. Lignin valorization: improving lignin processing in the biorefinery. Science. 2014;344:1246843.

14. Lopez F, Diaz MJ, Eugenio ME, Ariza J, Rodriguez A, Jimenez L. Optimization of hydrogen peroxide in totally chlorine free bleaching of cellulose pulp from olive tree residues. Bioresour Technol. 2003;87:255-61.

15. Stoklosa RJ, Hodge DB. Fractionation and improved enzymatic deconstruction of hardwoods with alkaline delignification. Bioenerg Res. 2015;8:1224-34

16. Linger JG, Vardon DR, Guarnieri MT, Karp EM, Hunsinger GB, Franden MA, Johnson CW, Chupka G, Strathmann TJ, Pienkos PT, et al. Lignin valorization through integrated biological funneling and chemical catalysis. Proc Natl Acad Sci USA. 2014;111:12013-8.

17. Karp EM, Donohoe BS, O’Brien MH, Ciesielski PN, Mittal A, Biddy MJ, Beckham GT. Alkaline pretreatment of corn stover: bench-scale fractionation and stream characterization. ACS Sustainable Chem Eng. 2014;2:1481-91.

18. Banerjee G, Car S, Liu T, Williams DL, Meza SL, Walton JD, Hodge DB. Scale-up and integration of alkaline hydrogen peroxide pretreatment, enzymatic hydrolysis, and ethanolic fermentation. Biotechnol Bioeng. 2012;109:922-31.

19. Banerjee G, Car S, Scott-Craig JS, Hodge DB, Walton JD. Alkaline peroxide pretreatment of corn stover: effects of biomass, peroxide, and enzyme loading and composition on yields of glucose and xylose. Biotechnol Biofuels. 2011:4:16.

20. Correia JA, Junior JE, Goncalves LR, Rocha MV. Alkaline hydrogen peroxide pretreatment of cashew apple bagasse for ethanol production: study of parameters. Bioresour Technol. 2013;139:249-56.

21. Gould JM. Studies on the mechanism of alkaline peroxide delignification of agricultural residues. Biotechnol Bioeng. 1985;27:225-31.

22. Gould JM. Alkaline peroxide delignification of agricultural residues to enhance enzymatic saccharification. Biotechnol Bioeng. 1984;26:46-52.

23. Gould JM, Freer SN. High-efficiency ethanol production from lignocellulosic residues pretreated with alkaline $\mathrm{H}_{2} \mathrm{O}_{2}$. Biotechnol Bioeng. 1984;26:628-31.

24. Alvarez-Vasco C, Zhang X. Alkaline hydrogen peroxide pretreatment of softwood: hemicellulose degradation pathways. Bioresour Technol. 2013;150:321-7

25. Ayeni AO, Hymore FK, Mudliar SN, Deshmukh SC, Satpute DB, Omoleye JA, Pandey RA. Hydrogen peroxide and lime based oxidative pretreatment of wood waste to enhance enzymatic hydrolysis for a biorefinery: process parameters optimization using response surface methodology. Fuel. 2013;106:187-94.

26. Jung YH, Kim HK, Park HM, Park YC, Park K, Seo JH, Kim KH. Mimicking the Fenton reaction-induced wood decay by fungi for pretreatment of lignocellulose. Bioresour Technol. 2015;179:467-72. 
27. Li Z, Chen CH, Hegg EL, Hodge DB. Rapid and effective oxidative pretreatment of woody biomass at mild reaction conditions and low oxidant loadings. Biotechnol Biofuels. 2013;6:119.

28. Li Z, Chen CH, Liu T, Mathrubootham V, Hegg EL, Hodge DB. Catalysis with $\mathrm{Cu}(\mathrm{II})$ (bpy) improves alkaline hydrogen peroxide pretreatment. Biotechnol Bioeng. 2013;110:1078-86.

29. Lima MA, Lavorente GB, da Silva HK, Bragatto J, Rezende CA, Bernardinelli OD, Deazevedo ER, Gomez LD, McQueen-Mason SJ, Labate CA, et al. Effects of pretreatment on morphology, chemical composition and enzymatic digestibility of eucalyptus bark: a potentially valuable source of fermentable sugars for biofuel production-part 1. Biotechnol Biofuels. 2013;6:75.

30. Behr A, Tenhumberg N, Wintzer A. An efficient reaction protocol for the ruthenium-catalysed epoxidation of methyl oleate. Eur J Lipid Sci Tech. 2012;114:905-10.

31. Guidotti M, Pirovano C, Ravasio N, Lazaro B, Fraile JM, Mayoral JA, Coq B, Galarneau A. The use of $\mathrm{H}_{2} \mathrm{O}_{2}$ over titanium-grafted mesoporous silica catalysts: a step further towards sustainable epoxidation. Green Chem 2009;11:1421-7.

32. Kholdeeva OA. Recent developments in liquid-phase selective oxidation using environmentally benign oxidants and mesoporous metal silicates. Catal Sci Technol. 2014;4:1869-89.

33. Battioni P, Renaud JP, Bartoli JF, Mansuy D. Hydroxylation of alkanes by hydrogen-peroxide-an efficient system using manganese porphyrins and imidazole as catalysts. J Chem Soc Chem Comm. 1986;4:341-3.

34. Kim J, Harrison RG, Kim C, Que L. Fe(TPA)-catalyzed alkane hydroxylation. Metal-based oxidation vs radical chain autoxidation. J Am Chem Soc. 1996;118:4373-9.

35. Chen K, Costas M, Kim JH, Tipton AK, Que L. Olefin cis-dihydroxylation versus epoxidation by non-heme iron catalysts: two faces of an Felll-OOH coin. J Am Chem Soc. 2002;124:3026-35.

36. Yu ZY, Jameel H, Chang HM, Park S. The effect of delignification of forest biomass on enzymatic hydrolysis. Bioresour Technol. 2011;102:9083-9.

37. Himmel ME, Ding SY, Johnson DK, Adney WS, Nimlos MR, Brady JW, Foust TD. Biomass recalcitrance: engineering plants and enzymes for biofuels production. Science. 2007;315:804-7.

38. Ragauskas AJ, Nagy M, Kim DH, Eckert CA, Hallett JP, Liotta CL. From wood to fuels: integrating biofuels and pulp production. Ind Biotechnol. 2006;2:55-65

39. Liu T, Williams DL, Pattathil S, Li M, Hahn MG, Hodge DB. Coupling alkaline pre-extraction with alkaline-oxidative post-treatment of corn stover to enhance enzymatic hydrolysis and fermentability. Biotechnol Biofuels. 2014;7:48.

40. Koo BW, Treasure TH, Jameel H, Phillips RB, Chang HM, Park S. Reduction of enzyme dosage by oxygen delignification and mechanical refining for enzymatic hydrolysis of green liquor-pretreated hardwood. Appl Biochem Biotech. 2011;165:832-44.

41. Draude KM, Kurniawan CB, Duff SJB. Effect of oxygen delignification on the rate and extent of enzymatic hydrolysis of lignocellulosic material. Bioresour Technol. 2001;79:113-20

42. Yuan TQ, Wang W, Xu F, Sun RC. Synergistic benefits of ionic liquid and alkaline pretreatments of poplar wood. Part 1: effect of integrated pretreatment on enzymatic hydrolysis. Bioresource Technol. 2013;144:429-34.

43. Agbor VB, Cicek N, Sparling R, Berlin A, Levin DB. Biomass pretreatment: fundamentals toward application. Biotechnol Adv. 2011;29:675-85.

44. Li MY, Foster C, Kelkar S, Pu YQ, Holmes D, Ragauskas A, Saffron CM, Hodge DB. Structural characterization of alkaline hydrogen peroxide pretreated grasses exhibiting diverse lignin phenotypes. Biotechnol Biofuels. 2012;5:38.

45. Williams DL, Hodge DB. Impacts of delignification and hot water pretreatment on the water induced cell wall swelling behavior of grasses and its relation to cellulolytic enzyme hydrolysis and binding. Cellulose. 2014;21:221-35.

46. Ko JK, Kim Y, Ximenes E, Ladisch MR. Effect of liquid hot water pretreatment severity on properties of hardwood lignin and enzymatic hydrolysis of cellulose. Biotechnol Bioeng. 2015;112:252-62.

47. Zhang L, You T, Zhang L, Yang H, Xu F. Enhanced fermentability of poplar by combination of alkaline peroxide pretreatment and semisimultaneous saccharification and fermentation. Bioresour Technol. 2014;164:292-8.

48. Zhang JZ, Gu F, Zhu JY, Zalesny RS. Using a combined hydrolysis factor to optimize high titer ethanol production from sulfite-pretreated poplar without detoxification. Bioresour Technol. 2015;186:223-31.

49. Lucas M, Hanson SK, Wagner GL, Kimball DB, Rector KD. Evidence for room temperature delignification of wood using hydrogen peroxide and manganese acetate as a catalyst. Bioresour Technol. 2012;119:174-80.

50. Grabber JH, Ralph J, Lapierre C, Barriere Y. Genetic and molecular basis of grass cell-wall degradability. I. Lignin-cell wall matrix interactions. CR Biol. 2004;327:455-65.

51. Klein-Marcuschamer D, Oleskowicz-Popiel P, Simmons BA, Blanch HW. The challenge of enzyme cost in the production of lignocellulosic biofuels. Biotechnol Bioeng. 2012;109:1083-7.

52. Lynd LR, Laser MS, Bransby D, Dale BE, Davison B, Hamilton R, Himmel M, Keller M, McMillan JD, Sheehan J, et al. How biotech can transform biofuels. Nat Biotechnol. 2008;26:169-72.

53. Gao X, Kumar R, Singh S, Simmons BA, Balan V, Dale BE, Wyman CE. Comparison of enzymatic reactivity of corn stover solids prepared by dilute acid, AFEX, and ionic liquid pretreatments. Biotechnol Biofuels. 2014;7:71.

54. Kumar L, Chandra R, Saddler J. Influence of steam pretreatment severity on post-treatments used to enhance the enzymatic hydrolysis of pretreated softwoods at low enzyme loadings. Biotechnol Bioeng. 2011;108:2300-11.

55. Kim Y, Kreke T, Ko JK, Ladisch MR. Hydrolysis-determining substrate characteristics in liquid hot water pretreated hardwood. Biotechnol Bioeng. 2015;112:677-87.

56. Yamamoto M, lakovlev M, Bankar S, Tunc MS, van Heiningen A. Enzymatic hydrolysis of hardwood and softwood harvest residue fibers released by sulfur dioxide-ethanol-water fractionation. Bioresour Technol. 2014;167:530-8

57. Zhu W, Zhu JY, Gleisner R, Pan XJ. On energy consumption for size-reduction and yields from subsequent enzymatic saccharification of pretreated lodgepole pine. Bioresour Technol. 2010;101:2782-92.

58. Li Z, Bansal N, Azarpira A, Bhalla A, Chen CH, Ralph J, Hegg EL, Hodge DB. Chemical and structural changes associated with Cu-catalyzed alkalineoxidative delignification of hybrid poplar. Biotechnol Biofuels. 2015;8:123.

59. Sluiter A, Hames B, Ruiz R, Scarlata C, Sluiter J, Templeton D, Crocker D. Determination of structural carbohydrates and lignin in biomass. Technical Report NREL/TP. 2011;10:42618.

\section{Submit your next manuscript to BioMed Central and we will help you at every step:}

- We accept pre-submission inquiries

- Our selector tool helps you to find the most relevant journal

- We provide round the clock customer support

- Convenient online submission

- Thorough peer review

- Inclusion in PubMed and all major indexing services

- Maximum visibility for your research

Submit your manuscript at www.biomedcentral.com/submit
() Biomed Central 